\title{
Family Ties and Child Placement
}

\author{
FERNANDO COLÓN, PH.D. ${ }^{a}$
}

${ }^{a}$ Counseling Center and Department of Psychology. University of Michigan Ann Arbor, Michigan.

The fundamental premise of this paper is the primacy of the child's experience of biological-familial continuity in establishing his sense of self and personal significance. This paper examines the effects of current child placement practices on the child's ties to his biological, foster, and adoptive families. It explores alternative practices that would take into account biological-familial continuity. Comment is invited.

In a real sense, this paper can be thought of as a sequel to my identity paper (6), in which I describe my experience as a foster child and my successful reestablishment of contact with my biological-extended families. At the end of that paper I raised a number of questions about the need and the right of the individual to "know" his biological and familial roots. This paper is an attempt to begin to answer those questions and, I hope, deepen our understanding of the complex and rich relations between a person and his biological families, both immediate and extended.

The central premise of this paper is that the child's experience of biological-familial continuity and connection is a basic and fundamental ingredient of his sense of self, his sense of personal significance, and his sense of identity. It is my contention that consistent consideration given to this premise would result in better child placement practice and procedure. Painful ruptures that particular life circumstances cause for some children and their biological parents and extended families can be offset. The critical issue is the maintenance of the child's and the biological families' mutual emotional bondedness so that the child grows up, at the very least, emotionally connected to his biological families and, if possible, with tangible connections as well. Both child and parents can retain a reciprocal sense of themselves and a sense of their roles in a still larger family system.

The goal of this paper is to examine the effects of current child placement practices on the child's ties to his biological families and, in some cases, foster families. Although the relation between family ties and the placement of children has in the past and there is an extensive literature on the topic summarized by Kadushin (11), this tissue has not been addressed systematically across a variety of child placement settings such as care of children of divorced parents, foster care, adoptive care, and the placement of children in crossracial and crosscultural settings. This paper will explore the way child placement policy and practice might function if the reality of both the child's ties to his biological family and their ties to him were deliberately considered in planning for her or his placement.

For the purposes of this paper the family system is defined as all members of the child's family both living and dead who are biologically related to one another. As well as all members of the step-family, foster family, or adoptive family. Included are all members of the nuclear family and extended family on both sides.

Murray Bowen $(3,4)$ was one of the first family theorists to understand and to describe the interconnectedness among the various parts of the nuclear and extended family systems. Ivan B. Nagy and Geraldine Spark (2) have richly enlarged our view of the way family ties function in their book, appropriately entitled, Invisible Loyalties: Reciprocity in Intergenerational Family Therapy (2). Salvatore Minuchin et al. (20, 21, 22), in their work with ghetto families, have focused their attention upon the continuously impacting ecological system composed of the larger social-economical-political contexts such as neighborhood, school, church, courts, and welfare agencies that daily affect the life of the family. They are concerned also with familial intergenerational contextual factors.

It is becoming increasingly clear that when a child is cut off from his biological family system there is for the child, the parents, and the families involved a deep mutual sense of personal loss. Weiss (30) and Roman (25) speak of this loss with regard to the children and parents of divorced families. Colón (6) and McAdams (18) speak of this loss for children and parents who experience foster-child placement. Benet (1) and Trisiliotis (27) address this loss as it applies to children and parents who experience adoptive placement. Haley's book, Roots, (9) does not focus directly upon the crossracial and crosscultural placement of children, but the story still speaks powerfully to such arrangements. The uprooting of African blacks for the slave market and the crossracial and crosscultural adoption of Korean and Vietnamese children inevitably involves profound loss of racial, ethnic, and cultural ties in addition to familial cut-offs.

These considerations suggest the hypothesis that persons who experience unresolved emotional cut-offs from significant others are persons at higher risk emotionally and psychologically than those who have resolved such cut-offs. The psychological response on the part of the person who has lost contact with a "familial-other" because of permanent cut-offs in family ties is strikingly similar to the reaction one sees in persons who are bereaved by the death of a loved one. When my ten foster brothers left our foster home at different times, there was no opportunity for further contact with them. I experienced their leaving and the permanent cut-offs from them as a series of depressions. I was forced to work my way 
through a series of mourning reactions (6). The empirical evidence for this hypothesis is not as yet well established, but the work of Weiss (30), Wallerstein and Kelly $(28,29)$, and Hetherington et al. (10) with divorced families and the work of Trisiliotis (27) with adopted persons clearly supports such a hypothesis.

Implicit in the principle of continuity with biological-familial roots is an assumption that deep, enduring, reciprocal loyalty commitments throughout the course of life are better for the child, the individual, the family, and the larger community. As one observes contemporary American culture, one is impressed by the degree to which powerful societal forces operate toward the loosening and the breaking down of family ties. There is a decline of tradition as essential. There is a disregard of moral and social restraints on all levels of behavior. There is an increasing preoccupation with self and self-realization at the expense of the family or the community. There is an endemic mobility to American life that contributes to a deep inner sense of rootlessness and emptiness whereby we pursue success at the expense of personal and familial relationships. The divorce rate is truly alarming. People seem to be less willing to make deep long-term and enduring commitments.

Given such societal forces it is no wonder that child placement practices are not conscious of the need for a child and his family to retain mutual ties but tend rather to accentuate further society's acceleration toward fragmentation. When one moves from the placement of children of divorced parents, to foster care, to adoptions, to cross-racial and crosscultural adoptions, to artificial insemination, and finally to the latest development, i.e., embryo transplants, what one sees is a progressively increased degree of being cut off from one's biological rootedness. This is not to say that all child placement workers deliberately set out to pull children further and further away from their roots. Indeed, many workers are acutely aware of these societal pressures and consciously act to resist them. Rather, it is to say that some child care workers do place children without adequate attention to the principle of family continuity largely because societal forces do not seem to value the maintenance of family ties.

This paper makes a plea for the primacy of the child's and the adult's birthright to have access to the biological rootedness of their existence. The birthright can be given in a variety of ways. This paper will explore the birthright issue as it plays itself out in our concern for children, parents, and families affected by divorce and our concern for foster children and adopted children. The sympathetic reader will like what he reads. The unsympathetic reader will be critical because he substantially disagrees and because the applications of the idea of family continuity in this paper will be fragmentary and incomplete. Nevertheless, I hope whether or not you are sympathetic, you will join me in our common struggle to understand this emotionally loaded but compelling human issue.

\section{The Placement of Children of Divorced Parents}

There are approximately one million divorces per year in the United States. We can now expect that at least one out of every three marriages will end in divorce. If we aim at maintaining family ties, these facts confront us with the complex problem of how to provide ongoing continuity to both parents for the children of divorced families. It is typical in our culture for the mother to have custody rights to the child with the father receiving visitation rights. This practice often overemphasizes the child's ties to his mother rather than fostering a balance and ongoing connection with both mother and father. It is important to keep in mind that although the divorce ends the parents' marriage to each other, it does not end the child's need for continuous connection to each parent. The goal in this situation is to enable the child both to work through his feelings about the divorce and to have the opportunity to engage in "ongoing, reciprocally supportive relationships within each of his extended families as he moves through each and every phase of his life" (26).

The issue of custody rights has been addressed by the Eastern Pennsylvania Psychiatric Institute group. They state:

In our view, the best custodial parent is not the parent who can provide the best material resources or who is most intelligent or intellectual or socially oriented. In our experience, the best custodial parent is the one who insures continuity of significant relationships for the children ... who insures that the children will have access to the other parent, to both sets of grandparents, to extended family members on all sides. [23]

Divorced parents cannot ignore the challenge of finding ways to become a continuing and effective parenting team, to learn to cooperate with each other so that together they can develop wholesome and mutual ties between their child and each of them and their respective families of origin. The quantity of time spent with the child is less important than offering the child evidence on both sides of parental commitment, devotion, and guidance.

The EPPI group has learned that a determined effort must be made to reconnect the child to the absent parent. Even if unsuccessful, the fact of the attempt is meaningful. Its genuineness is crucial to the child's sense of the custodial parent's fairness. The child learns that his own tie to the absent father is more important than the differences that caused his parents to divorce. This idea is exemplified by a man's question to B. Krasner, a member of the EPPI team:

"My wife left me during her pregnancy. Can I expect a normal relationship with my child, since it will not be with 
me from birth?" Krasner: "If 'normal' means living day by day with that child, no. But if 'normal' means letting that child know that he or she has a father and, in the long run, has a lifetime to spend on drawing on the resources of that father, absolutely! You need to claim a relationship with your child."[23]

Roman (25) has focused his attention upon the fact that the courts' continued practice of granting custody rights to one parent results in damage to all of the parties involved. He is concerned about the court's perpetuation of a system that he contends is clearly not working. He convincingly advocates joint custody of children with shared parental responsibility, an arrangement that he strongly believes works much better.

It is not uncommon in clinical practice to encounter clients whose parents have divorced, who remained with their mothers, and who have no further contact with their fathers.

A 20-year old, single woman's parents divorced when she was eight years old. After the divorce she never again saw her father who moved out of the state. She had difficulty sustaining satisfying relationships with men. After several months of therapy, she decided to find her father, to meet with him, and, she hoped, to get his view of the divorce. She was successful in this effort and was able to surprised when he accepted her warmly and did not reject her as she had anticipated from her mother's denigrating descriptions of him. She was able to achieve a better, more balanced view of her mother, her father, and herself. She began to feel more comfortable and acceptable in her relationships with other men. Thus, her ability to confront her unresolved tie to her biological father began to have far-reaching and positive effects upon her life.

The parents of the divorced child also have their needs. Each parent needs to retain viable ties to his or her child and to remain significant in the eyes of the child. Each parent needs to work through the dislocating and often traumatic emotional experience of the divorce process itself. Both need to resolve the experience of emotionally separating from each other. Both need to resolve the extent to which they will retain contact with their ex-spouse's family for both themselves and for their child. Weiss (31) details a host of issues that confront the divorcing parents. It is quite clear that a balanced consideration of the needs of both the children and the parents is required if constructive resolutions are to be found for all the persons involved. Some of these issues are illustrated by the following case:

Sam, a 24-year-old, single male from a city ghetto background, sought therapy because of his high anxiety, his distrust of people, his social isolation, and his fear of acting out his hostile, bitter impulses. He had a history of drug addiction and alcoholism during his adolescence and was able to break his habit at a local drug treatment center in the city. When he was 14 , his parents were divorced after a long and stormy marriage. This event shattered him because he felt that both he and the family disintegrated at that time.

Although extremely ambivalent about therapy, he began treatment with a female therapist who worked with him supportively for six months. At the end of that experience a shift was made to explore the intrapsychic factors that played a continuing role in his problems. When he was transferred to me, we focused on reality issues such as college and his conflictual relationship with his girl. After trust was established, we addressed his ties to his mother and to his father.

Although his mother reared him after the divorce, he was distant from her emotionally. This pattern of distancing himself emotionally was replicated in his relationship with his girl. left the state when Sam was about 15 years old, and the boy had no further direct contact with him. We moved toward having Sam reestablish contact with his father by letter and by phone. His father responsed enthusiastically. While this was happening, his girl ended their relationship. Although he was quite shaken by this event, he weathered it well. He received significant financial support from his father as his senior year came to a close at a time that he had run out of money, was in debt, and had unpaid bills. This experience gave him a tremendous lift and proved to be a significant factor in his ability to push himself to complete his degree. Although his father was unable to attend his graduation, they made plans to visit with each other in the near future. It was clear that his father's positive response had a tremendous impact upon father's positive response had a tremendous impact upon Sam. Before, he had felt abandoned and rejected by his father and had developed a negative self-image. Seeing that his "bad" father was also 'good' began to break down his image of low self-worth.

It was also clear that reestablishing the tie to his son was an important event for the father as well. He had missed his son very much and felt excluded from his life after the divorce. At termination Sam made plans to continue therapy after he was relocated in order to do more work on his relationship with women and his unresolved tie to his mother.

When divorced parents remarry, it creates still further difficulties for the child. The child needs to be reassured that the remarriage does not end his relation with his biological father or mother. The child must also be helped to accept the new 
stepparents into his life. This process does not occur automatically. It takes time and commitment on the part of stepparents, biological parents, and the child. It needs ongoing attention to ensure still another source of support and growth for the child in his newly formed nuclear family.

At the time of their divorce Ted and Mary had three children, ages 9, 7, and 6. They agreed to remain within easy geographical reach of each other so that the children, who were to live with Mary, could readily visit with Ted. When Ted married Ann several years later, significant adjustments were required of everyone involved. The children actively disliked Ann, and Ted felt torn between his needs and the needs of his children. Mary also had her problems with Ted's new wife. Nevertheless, they all stayed with it and continued frequent visitations on a regular basis. Over time the hurts, resentments, and distortions were clarified. The children developed positive feelings toward Ann. A crucial aspect of this adjustment was Ann's realization that she could not be her stepchildren's mother. She could indeed be a significant, positive figure and resource person in their lives, but she could not take the place of their mother. Later, Ted and Ann had a child of their own, and this became another occasion for growth in the family. It was not an easy task to have the children accept the newcomer, Sue, and to define their relationship to her.

However, the commitment to maintain the old ties of the children to both biological parents and to develop new ties with Ann enabled them over a period of time to resolve significant familial attachment issues so that all their lives were enriched rather than desolated by the divorce and remarriage experience. Thus, they worked out a viable social contract even though the legal contract called for Mary to have custody of the first three children.

These ideas and suggestions are in sharp conflict with what is currently in practice today. A strong statement of one prevailing attitude is found in Beyond the Best Interests of the Child, coauthored by Goldstein, Freud and Solnit (8) who state:

Children have difficulty in relating positively to, profiting from, and maintaining the contact with two psychological parents who are not in positive contact with each other. Loyalty conflicts are common and normal under such conditions and may have devastating consequences by destroying the child's positive relationship to both parents. A "visiting" or "visited" parent has little chance to serve as a true object for love, trust, and identification, since this role is based on his being available on an uninterrupted day-to-day basis. Once it is determined who will be the custodial parent, it is that parent, not the court, who must decide under what conditions he or she wishes to raise the child. Thus the non-custodial parent should have no legally enforceable right to visit the child, and the custodial parent should have the right to decide whether it is desirable for the child to have such visits. [p. 38, italics added]

This view conflicts sharply with the EPPI group's position as well as my own. It is true that children have difficulty relating positively to two parents who are not in a positive relation with each other. But if the custodial parent chooses to sever the tie of the child to the noncustodial parent, no way for the child to fully resolve his relationship to the cut-off parent. Cutting the child off from the noncustodial parent may provide temporary relief from conflict but only at the cost of burying that conflict. The divorce must not diminish the importance of the child's need for a continued tie with his father. Absence of such contact can have a serious impact not only on the child's ability to relate wholesomely to his father but to other men for the balance of his life.

The goal should be to bring the child and his parent into an awareness of their mutual indebtedness and to work toward the resolution of the inevitable loyalty conflicts that occur when parents divorce. Severing the tie to the noncustodial parent also gives the custodial parent an unfair and unjust amount of authority over the child created by both of them. Both parents should have equal say as to what is to become of the child's tie to each of them. I believe that the child's continuous contact with both parents over time will enable the child and parents eventually to resolve their feelings about the loyalty issues.

Indeed, I would like to posit that the noncustodial parent should have an enforceable right to visit his or her child if he or she wishes. To suggest otherwise is to invite a practice that does deep and profound violence to the child's opportunity to know himself in a whole way. It is precisely the severing of ties that damages the child's and the parents' sense of themselves, leaving them feeling bereft and incomplete. Failure to maintain family ties can have serious effects on the individuals involved:

Mr. and Mrs. W. sought therapy for themselves because of continual marital conflict. It was Mr. W.'s third marriage and Mrs. W.'s second. His first marriage at 19 lasted fourteen years. During that marriage he was unemployed for awhile, and his wife went to work to support the family. After he was employed again, he wanted his wife to quit her job and return to being a homemaker. She refused; they were unable to reconcile this difference and subsequently were divorced. Three years later he remarried. His second wife resented his continuing interest in his 
children from his first marriage and subsequently divorced him five years later. Mr. W.'s parents were divorced when he was 2 to 3 years old. He never saw his father again and became very attached to his mother. His mother remarried when he was 4 to 5 years old but did not get along with his stepfather.

Mrs. W.'s first marriage lasted until the accidental death of her husband. They had two girls. After her first husband's death, she focused her life upon rearing her children to whom she became very attached. She had little involvement with either her or her husband's extended families. Mrs. W.'s parents were not close emotionally; her father felt neglected and dominated by his mother. Mrs. W. was close to her mother and distant from her father. This pattern persisted into her current marriage. With her second marriage to Mr. W., the household consisted of Mr. W, Mrs. W. and her two adolescent daughters.

Conflict in the current marriage focused upon who was to be boss of the wife's children. Both Mr. and Mrs. W. were used to being in charge of the kids. Conflict escalated to the point of horrendous verbal fights and short, overnight separations on the part of husband. As therapy progressed, it became apparent that Mr. W.'s tie to his mother was stronger than his tie to his third wife. He was adamantly against the idea of examining his tie to his biological father and feared that interest in his father would jeopardize his relations with his mother. Instead, he focused his energy on what was wrong with his third wife and refused to examine or change himself in any way.

Mrs. W. acknowledged that her attachment to her daughters did prevent a close attachment to her husband and that perhaps she had not resolved her attachment to her deceased husband. The lack of resolution was captured by the fact that she insisted they live in the home she and her deceased husband had built, although they had the means to buy a different house. The marital conflict escalated, and they moved for a divorce as each found himself unable to resolve old ties and to build new ties between them. Mr. W.'s cut-off from his father probably had a major bearing on his inability to rebalance his ties to his mother, father, stepfather, and all three of his wives.

The following case illustrates the value of maintaining family ties:

Mr. Y. (45 years old) and Mrs. Y. (42 years old) sought conjoint therapy because Mrs. Y., had just learned about an affair that Mr. Y. had recently terminated. Mrs. Y. was extremely upset and enraged at her husband. The degree of her rage at her husband seemed to be out of proportion to her husband's behavior, although his behavior was indeed damaging to the marriage. It became clear that Mrs. Y.'s complaints about the affair and his continual overinvolvement over the course of the marriage with his extended family, his mother in particular, were justified, yet it did not account for all of the rage that she continued to heap upon his head.

Background data on Mrs. Y. revealed that her parents were divorced when she was 3 years old her mother remarried when she was 7 . She did maintain contact with her father until her marriage and for sometime thereafter. Her stepfather left her rearing completely in her mother's hands and did not relate comfortably to her. She also maintained contact with her father's extended family and was her paternal grandfather's favorite. At the time of therapy, she had not seen her father for five years.

Therapy focused on getting Mr. Y. to make his bond to his wife primary and his bond to his mother and extended families secondary. This process was aided by a two-hour session with Mr. Y. and his mother. He was able to make this shift, which strengthened his marital bond. The focus with Mrs. Y. was to get her in contact with her rage at her father and stepfather so that she would not continue to dump this rage on her husband. The goal was for her to reestablish contact with her father. She resisted this goal but did agree to a two-hour session with her mother in which all of these issues were explored in detail. The marriage subsequently improved to the point that they wished to stop therapy. In this case it appeared that because Mrs. Y. had retained significant ties her father and his extended family, the process of the resolution of her ties to her father, stepfather, and husband was facilitated. The husband's willingness to redefine his tie to his mother and his easy access to her was also critical in this process.

In working with the divorced family, the issue of visitation is indeed a knotty one. Goldstein et al. state that a "visiting" or "visited" parent has little chance to serve as a true object for love and identification because he or she is not available to the child on a day-to-day basis. This is an astounding statement in light of what we know about the complex processes of identification. Parental visits, even sporadic ones, can still have an enormous impact upon the child's sense of himself. Granted, irregular visits by the noncustodial parent are not the same as daily contact, but they are extremely valuable to the child because they have the integrating effect of telling the child, in part, who she or he is and where she or he came from.

Undoubtedly Goldstein et al. arrived at their position out of a genuine concern for the welfare of children who are often in very destructive families. Given the psychological warfare so common in these families, in which children do get emotionally and physically abused, their concern is well warranted. Their solution, however, goes too far; it further damages the child with the deeper injury of familial cut-offs.

Abusive parents can be visited on neutral ground in caseworkers' offices when the warfare has died down; care in the 
timing and the frequency of these visits is critical. But such visits can enable the child and the parents to work through their feelings and to redefine their relations based upon the realities occasioned by the divorce. It is important that the parents and children involved have the opportunity to choose when to have such visits and not be faced with the issue of whether to have such visits. Then the legal and social work structures can hold the parents accountable to the children and enable them to agree on constructive visitation arrangements.

\section{Foster-Child Placement}

When a child is placed in foster care, he is unavoidably wrenched from his biological family. No matter how benign the foster family, both the child and his biological parents react to and profoundly experience the rupture of their mutual family ties. Foster care of children, by definition, is meant to provide temporary care for the child when his biological family is unable to care for him adequately. One of the best single-volume sources that addresses this complex issue sensitively and comprehensively is Kline and Forbush-Overstreet's book, Foster Care of Children-Nurture and Treatment (12).

When an agency receives a family's request to place their child in foster care, the agency's initial response should focus on placing the child with some other member of the child's extended family. All too often agencies fail to look beyond the nuclear family, when in fact there may be cousins, aunts, uncles, or grandparents ready and willing to care for the child. Placement in the extended family would keep the child in the context of his biological family system and enable both child and parents to maintain their mutual ties. The following cases illustrates such a placement.

When Mario was 3 years old, his father was killed, and his mother had a nervous breakdown. He was placed in the custody of his maternal grandparents. He grew up in violent surroundings both within and outside of his home. At age 14, when the home became intolerably violent, he was placed in a halfway house because of acting-out behavior. After one year he was returned to his grandparents' home. He also lived occasionally with his mother who had remarried by then and was raising a large family. For a while he was involved with the street life of violence and drugs, but, seeing that this was leading nowhere, he enlisted in the army. After his discharge, he visited a friend in college who encouraged him to apply for an opportunity award; he did, was accepted, and went on to college.

When Mario sought therapy he was in an academic crisis, felt socially isolated, and was cut off from ongoing contact with his family. He had developed a pattern of letting all of his studies go until the day before the final exam. Then he would cram and expect himself to do better than anyone else. The pattern worked through his junior year but failed during his senior year. Once he realized that he did this to pump up his self-esteem, he saw that it was self-destructive and was able to change.

When we started therapy, Mario was estranged from his family. He felt he was the black sheep and that they had no interest in him. Since Christmas vacation was approaching, I encouraged him to be in touch with his family and to plan to visit them. He was able to do this and established meaningful contact with them for the balance of his senior year. He experienced a great sense of welcome and support from his family and no longer felt he was fighting the world all by himself. This support undergirded his academic effort, and he excelled. His senior year culminated in his being accepted by a prestigious law school. As therapy ended, he was aware that he still had a lot of unresolved rage that he believed he experienced because of his minority status. He realized that at some point in the future he might need to resume therapy in order to resolve those feelings.

Often we automatically go along with a family's request to put the child in foster care without fully examining why the family wants to extrude the child. The desire suggests that the child may be a symptom of trouble in the family, and if the symptom is removed, the family may move much slower toward addressing the family problem. By resisting the impulse to remove the child, the agency may be able to help the family directly and may not have to resort to foster placement at all.

One foster-care agency used to place twenty to thirty children each year in foster care. After shifting to a family perspective that made them scrutinize the reasons for foster placement, they offered family therapy instead and were able to reduced the number of placements to three to five a year (13).

This practice in no way negates the need to place children in foster care who truly need it. However, if foster care must be used, a major effort should be made to enable the child and biological families to retain mutual ties. This would involve the selection of foster parents who would support the child's continuing interest in and contact with his natural family, who would cooperate rather than compete with the natural parents for the attention of the child. The ideal foster parents would view themselves as additional parenting figures, not as replacement parents and would try to attenuate the foster child's inevitable loyalty conflict. B. Kranser, who is both a mother and a foster mother, speaks pointedly to this issue:

Most significant ... is the fact that our foster children's primary loyalties lie with their family of origin; and try as we did, we could not remake that reality. [14] 
Agencies should especially seek out foster parents who not only enjoy mutually satisfying marital relations but who also maintain "active" and mutually satisfying relations with their own families of origin. These will be the kind of foster parents who can cooperate with the child's biological family rather than seek to replace them. If the foster parents have distant relations or chronic conflict with their own families, they might be prone to overinvest in the foster child and seek to meet needs they were not able to satisfy in relations with their own families.

It is not at all uncommon for the child's ties to his biological family to be fragmented, ruptured, or even severed after he is placed in foster care. However, there are to heal such ruptures in familial continuity through periodic visits; yearly family reunions; and giving the child access to family scrapbooks, family photo albums, and family geneologies. Because in the past it was assumed that the child's continued contact with his biological family would cause loyalty conflicts and interfere with adjustment to his new foster home, the above suggestions are contrary to traditional practice. But if the child can maintain ties with both biological and foster family systems, his loyalty can be encouraged in both directions, thus reducing the possibility that the foster parents or the biological parents will be treated as scapegoats.

During its routine visits, the foster care agency can take a leadership role in enabling this process to occur. The practice, carried out consistently and sensitively, could keep the foster family from developing distorted fantasies about the biological family and vice versa. It would be enormously comforting to the foster child, reassuring him that he had not been abruptly cut off from his family as if suddenly they had all died. He would have a clearer sense of the distinction between the foster parents and biological parents and what the limits of those relations could be.

This practice would change the whole nature of the foster child's experience because it would provide stability, continuity, predictability, and a subsequent sense of security. It would enable her or him to develop strong realistic ties to both sets of parents and to resolve loyalty conflicts. The reality of the circumstances that necessitated the placement could be more readily assimilated. Thus the child would not be left bereaved but would still have access to rich options of identity and connection. Ideally, the child would be returned to his natural family and, because of the continued contact between both families, the return would be considerably less problematic. If the child is not returned to his natural family, however, the periodic visits should continue until he achieves majority; they will continue to enhance his sense of self and to counteract any feeling of being "different" because of having had no contact with the biological family. 1

People often criticize proposals for ongoing visits between the foster family and the biological family by asking what happens if the child's father or mother is psychotic, if the father or mother is in prison, or if the biological family has no interest in the child. What then? The human tendency in such cases is to shield the child from the pain of such unfortunate reality. And yet whenever there is such an extreme disruption in the continuity of a parent-child relationship, there is a profound sense of loss on both sides. A child cut off from his parent-even if the parent is imprisoned or hospitalized - could react to that loss with rebellious, delinquent, or depressed behavior. The parent who is cut off from his child could react to that loss with hostility or apathy to the child or active rejection. Again it would seem to be extremely important to maintain or reinstitute the ties that were broken. Parents in psychiatric hospitals and in prisons can be visited. Both parent and child can benefit from such visits. They can work out a relationship based on reality, not fantasy, and clarify any misapprehension of the child that she or he is to blame for his parents' condition. Understandably, this would be a painful process. However, it is hard to imagine that it would not be emotionally corrective to both parent and child or child-now-adult if ample time were devoted to the effort. The following case illustrates these issues:

Miss R. a 22-year-old graduate student, was the oldest of three sisters. Her mother had abdicated her maternal role to Miss R. who was often left with the care of her younger sibs. Miss R.'s mother would become violent when drunk, was diagnosed as schizophrenic, and was hospitalized on several occasions, once by Miss R. herself. Finally, because of her mother's violence, Miss R., from the age of 14 to 17 was placed in a half-way house for delinquent teen-age girls. She had always done well academically and was able to get scholarship support for college.

When Miss R. was 5 years old her father killed a man and had been in prison most of the years since that event. Before his imprisonment she had been his favorite child. They corresponded occasionally from the time she was 5 until she was 20 , when their correspondence ceased. She had seen her father a few times during her childhood when he was on parole, but he was jailed again after being involved in an armed robbery.

Miss R.'s relationships to men were conflictual and unsatisfying. At the time of therapy, she had not seen her father for over five years. Her contact with her mother was minimal and limited to occasional visits. When she sought therapy, she was depressed, anxious, over-extended, and socially isolated. She had poured her energies into four years of academic work and was emotionally and physically exhausted. In the process she had become more and more distant from her ghetto roots.

After establishing trust, we focused upon her lack of contact with her past, which understandably she was eager to forget. She began making every-other-weekend visits to her mother, her sisters, her old friends, her parish priest, nuns, and her old church choir. She was warmly received by these people, and she found that by reconnecting to them, her depression disappeared and she felt renewed energy to pursue her degree. 
Then she was encouraged to visit her father in prison. As we prepared for this visit, she acknowledged that she still felt like a 5-year-old emotionally in relation to him. The visit was very significant for her. She was able to meet with him for three hours, and they spent the time reviewing their histories for each other and getting reacquainted as adults. She discovered that he had kept a scrapbook of all her accomplishments and activities throughout her high school and college years. It was made up of clippings and reports sent to him and told to him by friends and relatives.

This was a pivotal experience for Miss R. She felt an additional source of emotional As therapy terminated because of her graduation, we began to explore her still unresolved tie to her mother. Time did not permit us to complete this task. Nor did her visit with her father magically resolve her problems with men. Nevertheless, she ended therapy having made significant gains.

Although caseworkers often do make genuine attempts to keep a child within the biological family, the pressure on the case-worker to place a child in foster care can be tremendous, as illustrated by this case:

A caseworker was working with a single parent who had been reported to protective services for abusing her 7-year-old-son, Dan. The whereabouts of the boy's father was unknown. Dan was extremely difficult for his mother to handle and was also stealing in school. The caseworker had instituted a behavior modification program with mother, son, and school. Dan stopped stealing, his mother stopped abusing him, and she responded to the care and support of the worker.

When the caseworker brought up the issue of termination, the whole situation collapsed. The mother began to beat Dan, and Dan started to act out again. The mother returned to the caseworker and demanded that her child be placed in foster care and that he not be returned to her until he was good. The caseworker felt exhausted by this turn of events and wanted to resolve it by placing the child in foster care because of her concern about Dan and because after a year of treatment she felt the mother was intractable.

The caseworker recounted her last session with the mother and Dan when the issue of his placement was addressed in a very heated emotional interview. The climax occurred when the child indicated his willingness to go to foster care and the mother, for the first time, showed some tearful emotion, which she quickly covered up. Assessment of the mother's history revealed that her own mother was ill from cancer from the time of the daughter's birth until her maternal grandmother died when the child was 6 years old. At that point the care of her alcoholic father fell upon the child's shoulders.

It became apparent that the event of termination triggered strong unresolved feelings in the mother about her own losses. It also did not appear to be accidental that the mother was having problems with her 7-year-old son at about the parallel age she was at the time of her own mother's death. Thus, the session signaled not the end of therapy but a new beginning.

As the case unfolded, the caseworker felt the support of her supervisor for her feelings of frustration. As she began to comprehend more fully what was happening within the mother, she began to believe that it could be of value to continue to see the mother and Dan. She decided not to place Dan in foster care but to continue work with both of them to help them resolve their relationship as well as to help the mother resolve her ties to her own mother.

This turnabout did not come easily because powerful emotional forces were operating on both the mother and caseworker to place the child. But by taking a position of holding off on placement as long as possible, the worker was able to reassess the situation and to see more fully what was occurring, thereby envisioning ways that she could continue to work in an effective way with the mother and her son.

Fortunately, this worker had the support of a supervisor who did not rush in and agree that placement of the child was the appropriate solution. Many workers do not have that support. Indeed, they often feel great pressure to cool the situation down. Thus, many of the ideas in this paper that suggest to workers that family ties should be maintained confront workers with seemingly insoluble problems. Not only families, supervisors, and agency directors, but schools and courts often are on the side of placement of children without continuity of family ties.

Although finding alternatives to foster care is not easy, it can and is being done. Minuchin (22) makes use of an ecological approach to address this issue. The ecological approach seeks to find natural systems of support that are available to the family. Such natural sources of support can include not only the extended family but the neighborhood, the school, the church, etc. By moving into the home and the community, the worker can frequently discover sources of support that can help sustain families rather than make interventions that shatter them.

The Lower East Side Family Union of New York City is an agency that was created in March 1974 to prevent the breakup of families. The Family Union coordinates and monitors the efforts of agencies such as the school, the court, the Public Health Department, and the Welfare Department by working out family service contracts by which the agencies 
agree to provide specific services and the families agree to cooperate. The Family Union puts a great deal of effort into building and reestablishing the informal neighborhood social networks that can also provide self-help. In 1976 the Family Union worked with 390 families, 141 of which were seen as high-risk families because they had problems that were similar to other families whose kids were being placed in foster care. As of the date of Bush's (5) article, in only ten of the 390 families was it necessary to place children in foster care. These placements were temporary and lasted only a few months; the average foster placement by traditional agencies is five years. Placing children in foster care is expensive. Preventive family counseling is significantly cheaper, the savings in emotional costs to the family immeasurable.

Although the last case had a positive outcome at that point, it would be naïve to assume that thereafter all will go well for the caseworker and the family. Many families have extremely limited resources both economically and emotionally. There is still a tremendous need for good foster homes - in fact the demand far exceeds the supply.

I would like to suggest that we deliberately set out to develop long-term foster-care homes for such children. Long-term foster care would be more permanent than temporary foster care but less permanent than adoptive care. It could be used in those situations in which limited economic, social, and emotional resources make it unlikely that the child's biological family would be able to take him back in the forseeable future. The foster family in long-term foster care would have custody rights that would assure to the child the continuity of care so critical in developing his sense of basic security. Guardianship rights and visitation rights for the biological family would ensure familial continuity. Since it is conceivable that the biological family could develop the necessary resources to be able to care for the child in the future, custody rights for the child should remain revocable. However, if they are revoked, the long-term foster family should have visitation rights to assure continuity for them and their foster child with whom they now share mutually significant ties.

A glimpse into how such an arrangement could work is offered by McAdams (18), whose six children were placed in foster care. After several years they were returned to her when she was able to care for them. Her experience strongly illustrates the need for the biological and the foster family to be able to work together in their mutual concern for the child.

Long-term foster care defined in this way might make it possible to find more foster homes. It is very difficult to find families that are willing to make short-term commitments to foster children. Even though the placement may last only a few months, significant attachments develop so that separations are inevitably painful. If the foster family had the assurance that they would be able to foster the child on a long-term basis, it is likely they would find it easier to make the kind of emotional commitment so necessary for the child's well-being.

Madison and Schapiro (17) propose still another category of foster placement that they call permanent foster care. This would apply to those cases in which the children are surrendered by their biological families and become legal wards of the state with guardianship vested in the agency. They believe this is a viable option for children unlikely to be adopted and whose continued contact with their biological families is thought to be destructive. Thus, in this category the biological parents' ties to the child are completely severed.

I am quite opposed to such a practice because, again, by severing the ties the long-term cost to the child may well outweigh the short-term gains. Again, I believe that the biological family should be able to retain visitation rights to their children at times that would be constructive. Visitation rights could still be retained even though the guardianship of the child rests with the agency. The guardianship with the agency secures the long-term continuity of care for the child while the visitation rights of the biological parents and child maintain the biological family ties.

\section{Adoptive Child Placement}

The adoption of children is a time-honored practice that has the effect of ensuring adequate parenting for children who might otherwise be sadly neglected. There is no question about the value of adoption in this regard. However, it is my working assumption that all children should have not only adequate parenting but also access to information about, and perhaps eventual contact with, their biological families. For most of us, knowledge of and parenting by our biological family occur simultaneously in organic, unifying way. For the adopted child whose ties are legally severed from his biological family, there is a profound separation of his biological sense of himself and his experience of being parented by his adoptive family.

Indeed, when the final adoption decree is awarded to the adoptive family, it is the court's and society's intention that the adopted child's ties to his biological family be permanently severed. "The effect of the final decree is to establish a parent-child relationship between the petitioner and the adopted child and to terminate all relationships between the child and the biological parents. When the final adoption order is granted, the child legally assumes the surname of his adoptive parents. A new birth certificate may be issued in his new name and the record of the adoptive proceedings is sealed" (11, p. 560).

However well intentioned the above process, there is a growing awareness of a dilemma resulting from the practice of attempting to erase the actual roots of a child's biological existence. Lifton, in the forward of Benet's The Politics of Adoption, (16) says: 
The adoption experience cannot be free of dislocated human arrangements. For the most part our society handles the dislocation by offering a substitute family, but at a price. That price is the suppression of the adoptee's "life story"- the psychological and practical excision of his or her personal history and biological connectedness. What has been excised is replaced by fantasy—the adoptee's, the adoptive parents', and society's. The fantasy ... begins with the falsification of the birth certificate and extends indefinitely around most of the adoptee's life process. [16, $p$. 1]

The unique feature of the adopted children's experience is that in a deep sense they do not really know who they are. This feeling can and does persist even though the adoptive child's early years in the adoptive family may have been quite positive. The desire to know one's biological origins and parentage results from a deeply felt psychological and emotional need, a need for roots, for existential continuity, and for a sense of completeness. To know who one's biological parents are or were, to know where one's skin color, facial features, body build, temperament, and talents come from is a powerful human desire that drives a person as he seeks to achieve a sense of wholeness about herself or himself. However, says Lifton:

The main message to the adoptee ... is that he must suppress his urgent impulse to know. The power of that impulse, whether overt or suppressed is underestimated. It is commonplace for adoptees, from childhood through adulthood, to search faces on the street for signs that some anonymous person may be his mother, or his father, sister or brother. But to actively seek concrete information, whether through organized search procedures or even persistent questions to adoptive parents, is apt to be equated (by adoptee and adoptive parents) with disloyalty and ingratitude. Every family has secrets, but the adoptee is unique in the extent to which his quest for the most fundamental details of his existence is a direct source of guilt. He has no choice but to adapt to a pervasive sense of separatedness and half-life. [16, pp. 2-3]

Trisiliotis (27) has done research on 70 adoptees who chose to uncover their biological and historical heritage. He was interested in the motivations for their search, their needs, and how they used the information they received. His book has much useful information. He divided his group of 70 into two groups: one wanted to meet the natural parents, the other wanted to secure family background information. He concludes:

... the majority of adoptees searching into their genealogical background and especially most, but not all, of those trying to find their birth-parents were unhappy and lonely people and a considerable number had had psychiatric help. [27, p. 160]

One could mistakenly conclude from his finding that those adoptees who seek to know their birth parents are disturbed in some way. Although it is likely to be true that the adoptee is upset on some level about his lack of full knowledge about himself, I suspect that underneath that disturbance lies a healthy drive to know himself fully and completely in a biological, existential, and historical sense. Powerful statements regarding these issues may be found in Rod McKuen's (19), Ann Fisher's (7), and Betty Jean Lifton's (15) accounts of their search for ties to their biological families.

When the adoptees succeed in identifying and locating their biological parent(s), there is a fairly typical sequence of events. Again, Lifton says it well:

The sequence usually includes a desperate, intense search; exhilaration and deep satisfaction at finding one's natural mother (or father); and then a profound letdown, a sense of disillusionment and sometimes depression, as one painfully surrenders the fantasies of a lifetime and absorbs the realization that the found parent is an ordinary human being, sometimes a troubled one, and that neither party knows quite what to do with this relationship. The long-range sense, however, is that the search and reunion have been profoundly valuable and necessary, the source of the adoptee's newly experienced sense of being grounded in reality, no longer a phantom or a replacement but a renewed human being who has re-entered the world on a different plane. What these emotions suggest is that everyday feelings of connection and self-definition depend upon being able to locate oneself in larger human continuity. [16, p. 5]

This need to know, however, is not a one-sided issue for the adoptee. There is growing evidence indicating that the adoptee's biological parents have a reciprocal need to know their relinquished children:

Many natural mothers (according to recent psychiatric studies) when "found" by the children they long ago gave up, experience emotions described as "relief" at learning that their child has made his or her way reasonably into adulthood, and above all diminution of guilt. Feelings vary and no situation is free of ambivalence. But increasing 
numbers of natural mothers are themselves embarking on a "search," and it turns out that many, over the years, experience symptoms similar to those of their children—studying faces, newspaper pictures and stories, marriage announcements, and yes, obituaries, looking for signs of the lost connection. What is at stake for each in the reunion is not the sudden formation of a new or ideal mother-child relationship but rather the re-establishment of connection, the filling in of a vital biological and historical story, the emergence of the self from a half-life to something approaching full existence. [16, pp. 5-6]

Unfortunately, the biological father, or so called putative father, has been all but neglected in the past in adoption proceedings. However, this is changing, and it is noteworthy that the biological father also has strong feelings about what is to become of his child when he is given a chance to explore his reactions to the adoptive event. Contrary to popular belief, the relationship of most parents who have out-of-wedlock children and give them up for adoption are not short-term, casual relationships. Kadushin (11) reports that in two recent studies, not only was the mother available for interviews to plan for the child's adoption but 70 to 80 per cent of the fathers were available as well.

Benet (1) notes that prior to two 1972 United States Supreme Court decisions (Stanley vs. Illinois and Rothstein vs. Lutheran Social Service of Wisconsin), the out-of-wedlock mother could, by herself, give consent to the adoption of the child. The child in this sense was fatherless. Benet suggests that because of these decisions the U. S. Department of Health, Education and Welfare warns that the putative father has custody rights to the child that must be considered at the point of the decision to relinquish the child for adoption. He must be given the opportunity to show that he is capable of being the child's custodian and must be personally served in any litigation that could affect his rights. It is hoped that these events will increase the putative father's involvement in the adoption process of his child.

Given the above considerations, how might we redefine our adoption procedures to meet the child's needs for secure, permanent parenting, on the one hand, and his right to know the roots of his existence, on the other hand? This is an extremely complex question, and I would be foolhardy indeed to suggest that what follows is anything more than an initial proposal. Nevertheless, I believe we need to begin to develop a better answer to this important question.

The rationale for severing all ties of the child to his biological family is to protect the privacy of the biological parent, to ensure the security of the adoptive child's relation to his adoptive parents, and to enable the adoption agency to carry out its task of placing the child in adoption. New thinking in this area must focus upon the issue of "severing all ties" and seek ways either to retain those ties or to enable the adoptee to reactivate them at a later date if he so chooses.

There are two major categories of adoption: early adoption, in which the aim is to place the child as quickly as possible in a permanent home before the child develops any conscious memories of his biological family, and late adoption, in which older children are placed in adoptive homes after they have acquired conscious, or preconscious, memories and experiences of their biological families.

\section{Early Adoption}

For the early adoptee, significant steps toward addressing the biological family ties could be taken by adoption agencies, biological parents, and adoptive parents at the point of application for such services. The biological parents could be told that the child, as it moves through childhood, adolescence, and young adulthood, will probably want to know something about her or his origins. The child may indeed choose to seek a reconnection with them at a later date in order to obtain an even more complete sense of self. Both biological and adoptive parents will need help in being able to accept the fact that it is the child's existential birthright to know who he is.

The biological parents must recognize that they have a major responsibility to take steps to ensure that their child will be able to know who he is. To this end, they can leave on file at the agency a complete social and medical history that includes names, ages, and addresses of themselves and family relatives. The adoptive family should be given all of this information at the point of adoption, except specific identifying data of the biological parents and family. Then, as the child grows, he can be given this information so that at the outset he has factual information about himself.

Trisiliotis' (25) work suggests that this be done in response to the child's questions, and at an early age, well before adolescence. If the birthright data were handled in this manner, the child could, at his own pace, assimilate the knowledge into his sense of self. When the early adoptee reaches majority, he should be given the option of learning the specific identifying data about himself and of seeking a reconnection with his biological family.

The adoptive parents must be helped to understand that their adoptive child's interest in his biological family in no way negates the importance and significance of his relationship with them. Their mutual tie to each other cannot be erased. The biological family, at the point of application for adoptive services, and at the point the child might seek a reconnection, needs to be assured that the reconnection in no way puts upon them the demand that they resume the parental role with their child, now young adult. Indeed, the adoption process resulted from their earlier decision to relinquish that parental role. Reality would not permit them to assume a role that is no longer appropriate, since the adopted young adult is now at 
majority. This is a lesson we all learn whether we have natural, foster, or adoptive children.

Ideally, the adopted child should be encouraged to relate to the biological family to the extent that he and the biological family desire to relate, while retaining his ties to his adoptive family. Adoption care agencies would have to play a major, post-adoption role in enabling families to negotiate such a relationship. This mode of handling the early adoptive placement of the child has obvious merit. It enables the child to be reared by a family able to care for him. It does not tamper with the realities of the child's actual roots of existence. It enables the child to activate his ties to the biological family at a time in his life when he is more capable of doing so. It does not force him to make a choice but helps him to have, if he so chooses, a meaningful tie and relationship to both his adoptive and his biological families. But, above all, it gives him a readily available way of completing his sense of self, if and when he is ready to do it, without going through the trauma that our current system of handling adoptions forces upon the person who seeks to know (i.e., hiring lawyers, detectives, going to court, etc.)

In the absence of such a procedure, all three sides of the adoption triangle are not prepared for later reunions nor provided support during the reunion event itself. Painful encounters can and do occur. When the adopted person sets out on his search alone, he may succeed in reconnecting to his biological family only to discover that they want nothing to do with him and indeed actively reject him. Or they react the other way and seek to totally and hungrily absorb him into their life. The adoptee in such a predicament can be helped to work out a connection with the biological family based on reality. If the biological parent rejects him, he can be encouraged to persist in his need for reconnection by contacting other members of his biological family; it is highly unlikely that all members of the biological family will actively reject a family member who "returns." In time, if the adoptee establishes ties to members of the extended family, he may succeed in effecting a connection with the rejecting biological parent himself. The adoptee can also defuse an overinvestment in himself by his biological mother or father by establishing ties with other members of his biological family.

For the adoptee who decides to find out who he or she is, the move itself toward the reunion will have the effect of reactivating many old and long-buried questions such as: What are my biological parents like? Which one do I look like? Why did they really give me up for adoption? Will they react acceptingly or reject me if I succeed in locating them? How would or could we relate to each other now?

If the adoptee succeeds in reconnecting with his biological mother or father or other family member, the event can be upsetting and traumatic, as well as exhilarating. It can be confusing and anxiety-provoking to find a biological parent who is less than the fantasied ideal, especially if the parent turns out to be psychotic, imprisoned, alcoholic, or physically ill. The clash of fantasy and reality can be painful and lead to an even greater state of confusion for the adoptee. Thus, the adoptee who succeeds in his search for connection to his biological family will need a strong, supportive relationship with a mature friend or professional counselor to help resolve such issues. Sometimes the "strong other" is the adoptee's adoptive parents. However, the fundamental fact at this point is that now with the reality available, the issue is resolvable.

Sometimes an adoptee who has had an unhappy adoptive childhood experience hopes to undo this circumstance by finding his biological parents in the hope that they will love and accept him unequivocally and thereby give him what he feels he didn't get from his adoptive family. Even if the biological family responds positively to the reunion, they cannot, in reality, "redo" the adoptee's childhood. Nevertheless, the reunion can be an occasion for working through realistic relations with both adoptive parents and biological family.

Some adoptees will choose not to know anything about their biological roots. Or they may be interested in whatever information is available but have no interest in seeking a reunion with their biological family. I think it is important to honor those choices as well. The primary concern is that all adoptees at least be given the opportunity to make a decision themselves as to whether or not they wish to pursue the issue. The recent phenomenon of hundreds of adoptees joining together in adoptees' associations to seek "open records" is poignant evidence that most adoptees still do not have that choice.

The usual passages of life often reactivate the adoptees' feelings about their human connectedness. The onset of adolescence, marriage, having one's own child, the death of a loved one, or a divorce can all have the effect of raising again the biological-tie issue for the adoptee. In the following case, an early adoptee, who was adopted at four months and whose adoptive parents had died, began her "search" after her marriage ended in divorce:

Mrs. J., a 41-year-old divorcee and mother of four children, entered therapy because she was having difficulty in her relations with men. The divorce reactivated her feelings about her human connectedness; her unresolved conflicts about her deceased, adoptive parents; and her fantasies about her biological parents. She felt a strong need to find her biological parents. She succeeded in locating and reconnecting with her mother within a year. This was a profoundly significant event for her because she was able to fill in gaps about herself, thus feeling more complete and secure. She did not look to her biological mother to be a parent but to be a person who enabled her to make a reconnection with her biological heritage and existence. Circumstances did not permit us to work through her concerns about her relations with men, to whom she tended to cling in an urgent, needy way that inevitably 
alienated them. However, I suspect that in the future these relations might take on less of an all-or-nothing quality because the reconnection to her biological extended family attenuated her urgent need for emotional connectedness. Had it been possible to work longer, I would have encouraged her to seek out other members of her biological family, especially the men. Thus she would have been enabled to address and resolve the issue of her relations with a number of significant men— her adoptive father, her ex-husband, the men in her biological family, and the current men in her life.

\section{Late Adoption}

Because of the scarcity of infants available for adoption—owing to the expanding use of contraception and abortion as well as to the fact that increasing numbers of young mothers are keeping their babies — the phenomenon of adopting older children has become more widespread. The situation for the late-adoptee child, who has conscious or preconscious memories of his biological or foster family or both, is decidedly different from that of the early adoptee. How best to handle this issue has not been clear. I am leery, however, of any practice that attempts to make the child forget his tie to his biological family or foster family. Indeed, the older the late-adoptee child, the bigger the eraser would have to be and the larger the piece of reality the child would have to erase. This approach cannot be constructive because reality cannot be erased.

The better course would be to work out ways in which the child could maintain his ties to the previous families and be adopted as well. This practice already exists and works well in those cases in which the adoption experience and the previous family connections are handled sensitively. It calls for adoptive families to cooperate with the previous families to maintain the child's family connections via visitation. "Adoption-with-connection" would appear to be a good choice for the older child whose biological family is unable to provide continuous care and is unlikely to be able to do so for the remainder of the child's childhood. It is also a step further in the relinquishment process for the biological family than is expected when the child is placed in long-term foster care.

If "adoption-with-family-connection" were instituted, it would make sense for these children to retain their own surnames so that this important part of their actual identity would not be denied. In order to recognize the crucial contribution of the adoptive parents as well as their needs and responsibilities, the last name of the child could be a hyphenated combination of his own last name and that of his adoptive father. It seems to me realistic to give both names equal weight and significance because that most aptly fits the actual reality situation.

These suggestions would enable the late-adoptee to fashion a whole sense of himself from ties to both his adoptive family and his previous families.

Sometimes the older child articulates the dilemma of being adopted and taken away from the biological family.

For example, a 9-year-old girl in the process of becoming adopted, said to her caseworker, "But I don't know how to say good-bye to my parents."

A 13-year-old adolescent girl, who initially refused to be placed in adoptive care when her elderly maternal grandmother was no longer able to care for her, feared that she would lose her very significant familial tie to her grandmother. Subsequent discussion involving the child, the grandmother, the worker, and the adoptive family clarified the issue. It was agreed that after adoption the child would be able to visit her grandmother. The girl then accepted the adoption.

The implementation of this approach is not easy because the emotional voltage surrounding these issues is so high. Each case is unique and has to be handled with great sensitivity and care.

Maggie was 5 years old when she was placed in foster care because her mother was too emotionally incapacitated to provide adequate maternal care. During the first year of the placement, with the goal of returning her to her biological home, the agency actively supported Maggie's ties to both her biological mother and the foster family by arranging for visits on neutral ground.

However, the visits proved to be extremely upsetting to Maggie. Although she asked that they be stopped, the visits were continued for another year. Eventually the agency did end the visits, which had continued to upset the child. The foster family then tried to adopt Maggie but her biological mother successfully appealed to the court to stop their action. Another year went by, and she was placed in another home for adoption. Again the biological mother appealed as yet another year went by, but this time the adoption was upheld.

During the final court proceedings, two psychiatrists stated opposing views: the child should have the reality of seeing her biological mother; the child should not be subjected to that painful reality and should be allowed, as 
much as possible to grow up as a carefree child. The biological mother's lawyer believed that she should be allowed visitation rights but acknowledged that he was not sure it would be healthy for the child. He thought the biological mother was not ready to take the child back at that time and that she might never be ready. The judge awarded custody to the adoptive agency, which placed Maggie, now 9 years old, in adoptive care after four years of foster care.

Currently, the adoptive agency doesn't want Maggie to have any further contact with her biological mother because Maggie has been adopted. Maggie's biological mother doesn't feel that way and has already visited the adoption agency in an attempt to see Maggie again. The agency stood firm and said no. I do not know if the agency plans for the child to have contact with the foster family who after four years had become significant others to Maggie. Maggie's father has dropped out of sight. He is reported to be schizophrenic.

Maggie's adjustment to her adoptive placement has been good. Although she still doesn't want to see her biological mother, she does write to her, thus maintaining some tie. Her adoptive family believes that the visits with the biological mother had been too devastating - they tore Maggie in two and left her very depressed. Her adoptive parents are firmly convinced that what Maggie needs now is no direct contact with her biological mother and ample opportunity to be a child free of such dilemmas.

The adoptive mother, Mrs. D., feels very sorry for Maggie's biological mother because she gave Maggie a lot when she was with her as an infant and toddler. The adoptive mother hopes that at some distant point in the future, Maggie and her biological mother will have direct contact.

Mrs. D. also has knowledge of how to reach Maggie's biological father's extended family. Mrs. D. believes that Maggie should have this connection too, but again at a later date when Maggie is mature enough to handle it with their support.

This case clearly suggests the inadvisability of insisting upon visits with the biological family without taking into account the psychological needs of all the parties involved. The critical measure in the situation is an assessment of how destructive the visits were for the child and the biological mother and an assessment of the adoptive family's capacity to provide secure continuity of care. Only when all three corners of the adoptive triangle are considered can a specific plan be designed. In this case it seems that the child's tie to her biological mother needs to be necessarily quite thin for the present and the immediate future. Later the connection can be thickened via visitation when the child and the biological mother are able to handle such visits in a mutually beneficial way. However, the visits cannot be constructive until Maggie knows that her adoptive home is secure and permanent to the extent that visits with her biological mother will not overwhelm her with the devastating fear that she will lose her adoptive home if she sees her biological mother.

In the following exceedingly difficult case, the issue is raised again of severing or maintaining the late adoptee's ties to the biological family.

Angie, a 2 $\frac{1}{2}$-year-old girl, witnessed her father brutally beating her mother before he succeeded in killing her. He had also sexually abused Angie. Since the traumatic event of her mother's death, Angie was placed in temporary foster care. Her father was convicted of his wife's murder and imprisoned.

Although Angie was doing well in foster care, she was still a very traumatized little girl. The goal of the social agency was to place her in permanent adoptive care and to sever all ties with the biological family. However, a paternal aunt and her family initiated court action to block the adoption claiming their natural right to the child as blood relatives.

The agency's psychologist believed that the placement of Angie in her father's sister's home would be the worst place for the child to be. To do so would force her to live with the fact that her father murdered her mother or that her father was in prison wrongfully convicted of murdering her mother. He felt that it would be impossible for her paternal aunt to prevent Angie from being reminded of her father and the traumatic events. He also felt that living with her aunt, Angie would very likely have subsequent contact with her father directly or indirectly. Another psychologist agreed that Angie deserved a new start at her age, and the agency concurred in recommending a permanent adoption without connection to the biological family.

As difficult as this case is, it is unfortunately not that uncommon. It confronts everyone involved with a series of agonizing human decisions. It is easy to identify with the social agency in their concerns about the child. But would placing the child in permanent adoptive care and severing all ties to the biological family actually resolve the issue? I think not. It will bury the issue, which is appropriate for now, but it will not resolve the issue for the child if the cut-off is permanently maintained. The child would lose her ties not only to her father and paternal extended family but to her maternal extended family as well. Such a loss would be considerable.

A possible solution to the complex problem of Angie's placement would be to place her in a late-adoptive-care setting 
with a planned, later reconnection to her biological family. This would be consistent with the fact that at her age she would be highly likely to retain conscious or preconscious memories of her mother and father and other extended family members. For the balance of her childhood she could be nurtured in the adoptive home. During this period her ties to her biological family would be dormant. After her psychological and emotional roots were solidly secured in her adoptive home, her ties to her biological family could be reactivated through visitation at an age when she could handle such meetings with adequate support. The tie to her biological father necessarily needs to be quite thin until she reaches a level of maturity to be able to deal with the painful reality that was a part of her life. At that time, perhaps after majority, she may need professional help to resolve her tie to her father. This would be a difficult task for her but one that would lead to important psychological and emotional gains. Again, I believe that the impulse to cut Angie off totally and permanently from her biological father and her biological extended families in an effort to protect her goes too far. Whether or not one chooses to move in the particular ways suggested above would depend necessarily upon a full assessment of Angie's biological extended family. My point is simply that, even in cases like this, I would not advocate the complete severance of all family ties.

\section{Crosscultural Adoption}

The issues regarding crosscultural adoptions are extremely complex. Often the lack of a means of support for these children in their own cultural setting dictates that they be transplanted to an alien culture in order to save their lives. But when, for example, children from Vietnam are adopted into American families, important familial, racial, linguistic, and cultural ties are severed simultaneously. The full impact of the disruption is often obscured when the children are young and in the process of adapting themselves to the new family, culture, and ethnic group, but when they reach adolescence, those severed ties resurface as each child asks the (by now almost impossible to answer) question, "Who am I?"

As they seek to answer this question, they will be faced with an array of very likely unanswerable questions, since the cut-off is probably permanent. We have to be available to these children and be committed to providing them with long-range follow-up. Without that commitment many of them will be unable to fully resolve and mourn their original familial losses. Very likely they will have difficulty handling their subsequent marriage and parenthood because of the feelings of abandonment and loss they will still carry.

This issue is movingly illustrated in the case of a young woman who was crossculturally adopted from Asia into an American family. This woman went through the poignant and painful process of resolving her early feelings of being attached to and abandoned by her biological family. As a mother, this resolution enabled her to begin feeding her own infant adequately and to reverse a pattern of abandonment so strong that she had been leaving her child to die slowly of malnutrition. Not all severed familial ties lead to such devastating outcomes, but that they do occur is evidence that the issue of rootedness is not to be taken lightly.

\section{Conclusion}

This paper has explored a design for child placement practice that would deliberately consider the reality of both the child's ties to his biological family and their ties to him. Four factors emerged repeatedly that bear on these child placement issues: continuity of care, visitation rights, the various configurations of parent-child triangles, and relinquishment.

The paper suggests a range of continuity-of-care options that can be thought of as a series of placement possibilities running along a continuum of familial connection with a strong, consistent degree of secure, continuous care for the child. On the continuum would be joint custody of children, short-term foster care, long-term foster care, adoptive care with familial connection, and finally adoptive care without familial connection.

Visitation rights, which ensure continuity of ties with the biological family, are inextricably interwoven with the factor of continuity of care. The meaning of the visit with the biological family must be clearly spelled out to the child so that he will not be overwhelmed by the fear and threat of losing his secure home base; the visits should not have the effect of making him feel that his placement situation is jeopardized in any way. Although there are many exceptions, generally the frequency of the visits can be seen to fall along a continuum. In the divorced family the child's visits may be quite frequent; for foster children and adoptive children, they may be progressively less frequent. But the visits, even if limited, have enormous value to all parties involved in maintaining a sense of wholeness about themselves. The issue of visitation is a salient one not only for biological parents but for biological grandparents as well. Some grandparents whose son has been divorced are beginning to press for visitation rights to their grandchildren (24) (maternal grandparents typically have greater contact).

Nevertheless, one can still ask, "Are there no exceptions to the principle of visitation for the child and his biological family?" The answer is, yes, of course. Visits at the wrong time will be more destructive than constructive. Necessarily, the thread of connection to one's biological family may need at times to be very thin, indeed—dormant perhaps, but never broken. Later when conditions are favorable, the dormant ties can be reactivated through photo albums, letters, phone calls, and eventually visits. There will, of course, always remain the option for anyone at majority to decide where he or she 
wishes to maintain biological family ties or any other family ties.

The third factor operating inevitably in all child placement situations is the various child-parent triangles. In the divorce situation, it will be the child in a triangle with his two parents. In the foster-care setting, it will be a triangle consisting of the child, his biological family, and the foster family. In the adoptive-care option it will be the child, the biological family, and the adoptive family. Bowen's work with family system triangles, Nagy's work with family loyalties, and Minuchin's work with current familial-contextual arrangements all have obvious applicability here. The aim would be to have the agency or the worker involved help the child and the families to resolve the harmful loyalty conflicts that such triangles set up. This would call for continuous contact of the child with both sides of the triangle but only at times that such contact could be constructive.

In general, the thinner the biological familial connection, the longer the resolution process is likely to take. Significant ties to both biological families and foster and adoptive families need not be seen as different from children's ties to both biological families in the standard family pattern.

This paper suggests that we can develop degrees of relinquishment defined by the particular child placement option that is used. Again, as one moves from divorce care to adoptive care without familial connection, a greater degree of relinquishment is appropriate. In crosscultural adoptions, although family ties are typically severed, efforts can be made to maintain racial, ethnic, and cultural ties.

Although this paper has focused upon the question of familial connectedness, when a child moves in the direction of such family continuity, the issue is raised of separation and individuation from the biological and placement-care families in order to achieve a sufficient whole sense of self. It is clear that it will be necessary to help children establish ties that are life-giving and life-supporting but not overly suffocating nor overly distant. Indeed, we all need to strike a realistic balance between togetherness and separateness, with freedom to move from one to the other.

Finally, I am acutely aware that the case-worker, the mental health professional, or the parent who wishes to implement some of the ideas suggested in this paper will inevitably be confronted with seemingly insoluble dilemmas. If the parent or worker attempts to help the child maintain biological family ties, he is not unlikely to encounter strong resistance from the other parent, his field supervisor, the child's family, the court, the school, or all of these. Nevertheless, the more we confront and think about these problems, the more we will find ways to solve them. To move in this direction will require a shift in orientation that will not come easily. I have no doubt that many persons and professionals will strongly disagree with the ideas presented in this paper. This would trouble me only if the disagreements do not lead to better solutions that enhance our ability to place children in ways that enrich them. Much more work needs to be done in this area in terms of exploration, practice, and definitive research. I hope readers will assist in this venture by active criticism and suggestions. In this way, we all stand to gain a more profound understanding of the processes by which human beings can become whole persons.

\section{REFERENCES}

1. Benet, M. K., The Politics of Adoption, New York, The Free Press, 1976.

2. Boszormeniyi-Nagy, I. and Spark, G., Invisible Loyalties: Reciprocity in Intergenerational Family Therapy, New York, Harper and Row, 1973.

3. Bowen, M., "The Use of Family Theory in Clinical Practice," Comp. Psychiat., 7, 345-374, 1966.

4. Bowen, M., "Toward the Differentiation of Self in One's Family of Origin," F. D. Andres and J. Lorio (Eds.). Georgetown Family Symposia: A Collection of Selected Papers, vol. I, Family Section, Department of Psychiatry, Georgetown University Medical Center, Washington, D.C., 1971-72, 1974.

5. Bush, S., "A Family Program That Really Works," Psychol. Today, 10, no. 12, 48-50, 1977.

6. Colón, F., "In Search of One's Past: An Identity Trip," Fam. Proc., 12, 429-438, 1973.

7. Fisher, F., The Search for Anna Fisher, Greenwich, Connecticut, Fawcett Publications, 1974.

8. Goldstein, J., Freud, A. and Solnit, A. J., Beyond the Best Interests of the Child, New York, The Free Press, 1973.

9. Haley, A., Roots, Garden City, New York, Doubleday, 1976.

10. Hetherington, E. M., Cox, M. and Cox, R., "Divorced Fathers," Fam. Coord., 25, 417-427, 1976.

11. Kadushin, A., Child Welfare Services (2nd ed.). New York, MacMillan Publishing Co., 1974, Chapters 9, $10,11$.

12. Kline, D. and Forbush-Overstreet, H., Foster Care of Children, Nurture and Treatment, New York, Columbia University Press, 1972.

13. Kramer, C., "Foster Care Tomorrow," Paper read at 4th Statewide Conference of the Child Care Association of Illinois, Chicago, Illinois, March 26, 1968.

14. Krasner, B., "The Issue of Conflicting Loyalties in Foster Care Relationships," Paper read at the Foster Parents Recognition Dinner, Reading, Pennsylvania, June 1, 1975. 
15. Lifton, B. J., Twice Born, New York, McGraw-Hill, 1975.

16. Lifton, R. J., Foreward to The Politics of Adoption, by M. K. Benet, New York, The Free Press, 1976.

17. Madison, B. and Schapiro, M., "Permanent and Long-Term Foster Family Care as a Planned Service," Child Welfare, 49, 131-136, 1970.

18. McAdams, P. J., "The Parent in the Shadows," Child Welfare, 51, 51-55, 1972.

19. McKuen, R., Finding My Father: One Man's Search for Identity, New York, Coward Publishing, 1976.

20. Minuchin, S., Montalvo, B., Guerney, B., Rosman, B. and Shumer, F., Families of the Slums, New York, Basic Books, 1967.

21. Minuchin, S., Families and Family Therapy, Cambridge, Massachusetts, Harvard University Press, 1974.

22. Minuchin, S., "The Plight of the Poverty Stricken Family in the United States," Child Welfare, 49, 124-130, 1970.

23. Nelton, S., "After Divorce Children Still Need Parents" (A six part series), Philadelphia Inquirer, July 11-16, 1976 (Cotroneo, M., 3rd part, July 13, 1976 and Krasner, B., 5th part, July 15, 1976).

24. New York Times News Service, "Grandparents Robbed of Their Role by Divorce," The State Journal Register, Springfield, Illinois, December 28, 1977, p. 14.

25. Roman, M., "The Disposable Parent," Paper read at the Association of Family Conciliation Courts, Minneapolis, Minnesota, May 11-14, 1977.

26. Sparks, G., Personal communication, August 31, 1976.

27. Trisiliotis, J., In Search of Origins_-The Experiences of Adopted People, London, Boston, Routledge and Kegan Paul., 1973.

28. Wallerstein, J. and Kelly, J., "The Effects of Parental Divorce: The Adolescent Experience," in E. J. Anthony and C. Koupernik, (Eds.), The Child in His Family, vol. 3, New York, John Wiley and Sons, 1974.

29. Wallerstein, J. and Kelly, J., "The Effects of Parental Divorce: Experiences of the Pre-School Child," J. Am. Acad. Child Psychiat., 14, 600-616, 1975.

30. Weiss, R., Marital Separation, New York, Basic Books, 1975.

Reprint requests should be addressed to Fernando Colón, Ph.D., Counseling Center, University of Michigan, 1007 East Huron Street, Ann Arbor, Michigan 48109.

\footnotetext{
${ }^{1}$ Although my father's visits to me when I was a foster child were aperiodic, they were extremely valuable. I "knew" who my father was, and by knowing him I came to know myself. This enabled me to have a clearer and stronger sense of myself. It is also worth noting that my foster mother had the wisdom to encourage me to take Spanish in high school even though she spoke German. I recall being at college and writing to my father in Spanish and my foster mother in German. Visits from my maternal great-uncle and first cousin and a paternal aunt and cousin when I was between 7 and 8 later turned out to be of rich significance to me as I succeeded, finally, in reconnecting with my extended families (6).
} 